\title{
Numerical Approaches for Estimating Daily River Leakage from Arid Ephemeral Streams
}

\author{
Leilei Min ${ }^{1,2,+}$, Peter Yu. Vasilevskiy ${ }^{3,+}$, Ping Wang $2,4, * \mathbb{D}$, Sergey P. Pozdniakov ${ }^{3}$ and \\ Jingjie $\mathrm{Yu}^{2,4}$
}

1 Hebei Key Laboratory of Water-Saving Agriculture, Key Laboratory of Agricultural Water Resources, The Innovative Academy of Seed Design, Center for Agricultural Resources Research, Chinese Academy of Sciences, Shijiazhuang 050021, China; 1lmin@sjziam.ac.cn

2 Key Laboratory of Water Cycle and Related Land Surface Processes, Institute of Geographic Sciences and Natural Resources Research, Chinese Academy of Sciences, 11A, Datun Road, Chaoyang District, Beijing 100101, China; yujj@igsnrr.ac.cn

3 Department of Hydrogeology, Lomonosov Moscow State University, GSP-1, Leninskie Gory, Moscow 119899, Russia; valenciacf@mail.ru (P.Y.V.); sppozd@geol.msu.ru (S.P.P.)

4 College of Resources and Environment, University of the Chinese Academy of Sciences, Beijing 100049, China

* Correspondence: wangping@igsnrr.ac.cn; Tel.: +86-10-6488-1192

+ These authors contributed equally to this work.

Received: 27 December 2019; Accepted: 9 February 2020; Published: 12 February 2020

\begin{abstract}
Despite the significance of river leakage to riparian ecosystems in arid/semi-arid regions, a true understanding and the accurate quantification of the leakage processes of ephemeral rivers in these regions remain elusive. In this study, the patterns of river infiltration and the associated controlling factors in an approximately 150-km section of the Donghe River (lower Heihe River, China) were revealed using a combination of field investigations and modelling techniques. The results showed that from 21 April 2010 to 7 September 2012, river water leakage accounted for 33\% of the total river runoff in the simulated segments. A sensitivity analysis showed that the simulated infiltration rates were most sensitive to the aquifer hydraulic conductivity and the maximum evapotranspiration (ET) rate. However, the river leakage rate, i.e., the ratio of the leakage volume to the total runoff volume, of a single runoff event relies heavily on the total runoff volume and river flow rate. In addition to the hydraulic parameters of riverbeds, the characteristics of ET parameters are equally important for quantifying the flux exchange between arid ephemeral streams and underlying aquifers. Coupled surface/groundwater models, which aim to estimate river leakage, should consider riparian zones because these areas play a dominant role in the formation of leakage from the river for recharging via ET. The results of this paper can be used as a reference for water resource planning and management in regulated river basins to help maintain riparian ecosystems in arid regions.
\end{abstract}

Keywords: river-aquifer interaction; numerical simulation; sensitivity analysis; MODFLOW; Heihe River

\section{Introduction}

Surface water and groundwater are important components of the terrestrial water cycle, and their interaction forms the surface morphology, controls the material and energy fluxes in the subsurface zone, and affects the riparian ecosystem [1,2]. However, as indicated by Sophocleous [3], the interactions between surface water and groundwater are complex, and obtaining a deep understanding of these interactions in relation to the climate, landform features, geology, and biotic factors remains a great challenge. Clearly, the exchange between surface water and groundwater is likely to become even 
more challenging due to the impacts of human activities and climate change [4,5], which caused the disappearance of approximately $90,000 \mathrm{~km}^{2}$ of permanent surface water between 1984 and 2015 [6].

Given that a streambed acts as the physical interface between the surface and subsurface of a stream $[7,8]$, the hydraulic properties of streambeds mainly control the interactions between the stream and the underlying aquifer [4,9-11]. However, as confirmed by numerous field investigations (e.g., [12-14]), the hydraulic properties of streambeds usually exhibit large spatial and temporal variations, which are mainly caused by continuous changes in the streambed properties (e.g., the topography or hydraulic conductivity) during erosion and sedimentation processes [7]. Significant changes in the hydraulic properties of streambeds may even occur during short flooding events [15]. Additionally, the thermal dynamics of streambeds induced by diurnal and seasonal fluctuations in the stream water temperature also greatly influence the hydraulic properties of the streambeds [16-18]. For intermittent rivers, which constitute more than $30 \%$ of the total length and discharge of the global river network $[2,19]$, the hydraulic properties of streambeds are even more variable due to constant alternation between dry and wet conditions $[1,16]$.

The states of the connections between streams and underlying aquifers exert another important influence on the flux exchange between surface water and groundwater [4]. For losing streams, when stream-aquifer systems are transformed from connected to disconnected systems, the lateral flow induced by capillarity or heterogeneity plays a vital role in the stream water and groundwater interaction [20-22]. Brunner et al. [23] provided a theoretical criterion for justifying the connection/disconnection states between a stream and the underlying aquifer and suggested that the disconnection problem could be solved via a fully coupled, variably saturated flow model. Therefore, in addition to the broad range of field methods (e.g., [24-27]) and associated analytical solutions e.g., $[17,28,29]$, numerical simulations have been widely applied to investigate stream-aquifer interactions at different scales because these simulations can analyze the influences of transient flows and streambed heterogeneity on surface-groundwater exchanges $[4,30]$.

Recently, interest in the interactions between intermittent streams and groundwater in arid and semi-arid regions has been continuously growing due to the unique role of these interactions in shaping fragile riparian ecosystems (e.g., [27,31-35]). It is clear that stream water leakage is the dominant recharge mechanism in such regions; however, the infiltration processes during various stream discharge patterns and the factors that control the stream-aquifer interactions in typical losing connected/disconnected river systems remain unclear. In this context, it is critical to quantify the potential impacts of the variations in the stream width and leakage coefficient [36,37], which vary greatly for intermittent rivers in arid regions [1], on stream-aquifer interactions.

The lower Heihe River Basin represents a typical extremely arid region in north-western China, where the mean annual precipitation is less than $50 \mathrm{~mm}$, while the mean annual evaporation can reach $1500 \mathrm{~mm}$ [38-40]. The lower Heihe River is characterized by intermittent streams, and the streambeds usually remain dry from April to June [41]. The hydraulic property dynamics of these streambeds were investigated in detail in recent studies (e.g., $[13,16,41])$, and the monthly river leakage was approximately estimated using the River (RIV) package of MODFLOW-2005 [42,43]. While this estimation was based on regional groundwater modelling, it lacked a detailed analysis of the influence of the stream/streambed dynamics on the water exchange between the stream and aquifer. Therefore, to fill this gap, the objectives of this study were to (1) quantify the daily river leakage rates by numerically simulating the flux exchange between the rivers and the underlying aquifers and (2) identify the predominant factors that control the river-aquifer interactions in intermittent dryland rivers using parameter sensitivity analysis.

\section{Materials and Methods}

\subsection{Study Area}

The study area is located in the lower reaches of the second largest inland river in north-western China (Figure 1) and is characterized by a hyper-arid climate with an annual precipitation of only 
$35 \mathrm{~mm}$ and an annual potential evaporation of approximately $1500 \mathrm{~mm}[38,40]$. Over the period of 1961-2015, the mean annual air temperature was $+9.09^{\circ} \mathrm{C}$, with a minimum monthly mean air temperature of $-11.23^{\circ} \mathrm{C}$ in January and a maximum monthly mean air temperature of $+27.05^{\circ} \mathrm{C}$ in July [16]. The topography of this area gradually declines from the southwest to the northeast, with an average slope of 1-3\%o, and the elevation is between 1127 and $820 \mathrm{~m} \mathrm{[44].} \mathrm{The} \mathrm{dominant} \mathrm{landscape} \mathrm{is}$ the Gobi Desert, which is composed of wind-eroded hilly land, desert, and alkaline soils [45].

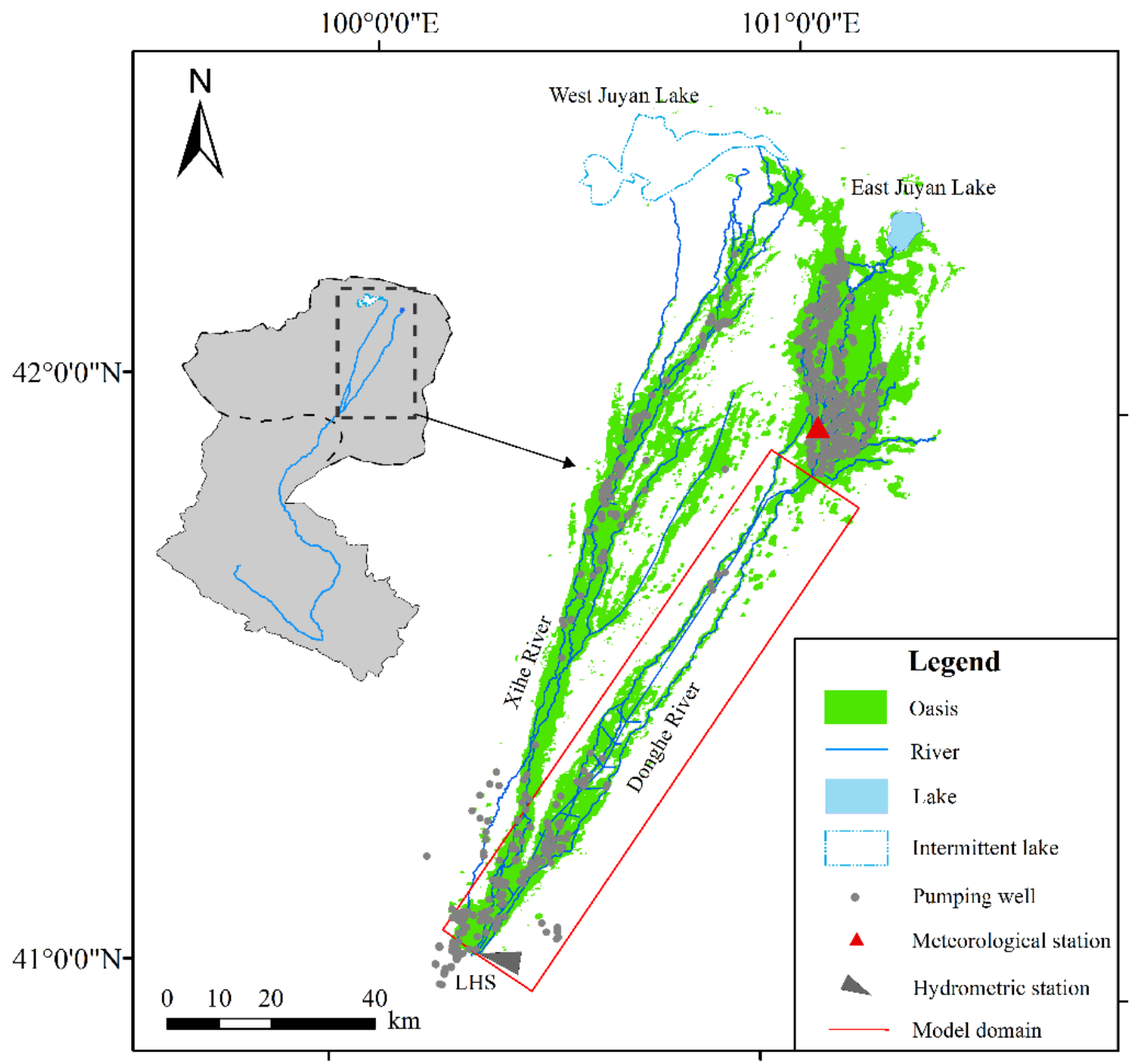

Figure 1. Study area and simulation domain. LHS represents the Langxinshan hydrometric station.

The study area is located in a regional tectonic basin where the bedrock is composed of Sinian $(\mathrm{Z})$ and Late Jurassic $\left(\mathrm{J}_{3}\right)$ formations. From the southwest to the northeast of the study area, the regional Quaternary (Q) aquifer system varies from a zone that consists of unconfined gravel and pebbles to a multi-layered zone that consists of sand and silt with a depth of several hundred metres [46,47]. In general, the phreatic aquifer is recharged by river water, and the groundwater flows from the southwest towards the terminal lakes and is then discharged via evaporation $[39,48]$.

The lower Heihe River, which is divided into two losing streams at the Langxinshan hydrometric station (LHS), i.e., the Donghe and Xihe rivers, flows through the Gobi Desert before entering terminal lakes (the East and West Juyan lakes) (Figure 1). At the LHS, the surface flow to the Donghe and Xihe rivers is regulated by a system of sluices. These river systems are the primary sources of shallow groundwater recharging via riverbed infiltration $[39,49]$ due to the relatively high vertical hydraulic conductivity [13]. The limited vegetation in the region is distributed along the rivers and relies on surface water and shallow groundwater in the riparian zone for sustenance [50-52]. More detailed 
descriptions of the study area are presented in Wang, Yu, Zhang, and Liu [48]; Wang, Yu, Pozdniakov, Grinevsky, and Liu [39]; and Yao, Zheng, Liu, Cao, Xiao, Li, and Li [42].

\subsection{Simulation of River Water and Groundwater Interactions}

\subsubsection{Simulation Domain and Boundary Conditions}

As noted by Wang, Pozdniakov and Vasilevskiy [16], approximately $71 \%$ of the total runoff was allocated to the Donghe River at the LHS from 1988 to 2015 (Figure 1). Additionally, the characteristics of the streambed sediment formation in the Donghe River are typical of the study area [13]. Therefore, the Donghe River was selected to analyze the water exchange processes between the river and the underlying aquifer. The simulation domain was determined according to the surface water and groundwater interaction zone during river flow events. Based on previous studies (e.g., [39,42,48,53]), the eastern and western boundaries of the model were determined by the regional flow direction, which was generally parallel to the river channel and approximately $10 \mathrm{~km}$ from the Donghe River. Thus, the eastern and western boundaries were generalized as no-flow boundaries. The southern and northern boundaries were at the LHS and Angcizha, respectively. The simulation domain is presented in Figure 1, and the total area of the simulation region was $2306.25 \mathrm{~km}^{2}$.

To focus on the river-aquifer interactions, the upper unconfined aquifer was simulated as spatially heterogeneous single-layer aquifer system. The top and bottom elevations of the aquifer are shown in Figure 2b,c. Based on geochemical data $[48,54]$ and the regional modelling of the groundwater flow system [42], the southern and northern boundaries of the model were designed as general head boundaries (GHBs) [55] in accordance with lateral groundwater flow from adjacent groundwater basins into the study area. The flux at the top boundary was determined according to the meteorological conditions, surface water and irrigation water infiltration, and evapotranspiration (ET) processes. The bottom of the aquifer was considered impermeable; therefore, the bottom boundary was designed as a no-flow boundary.

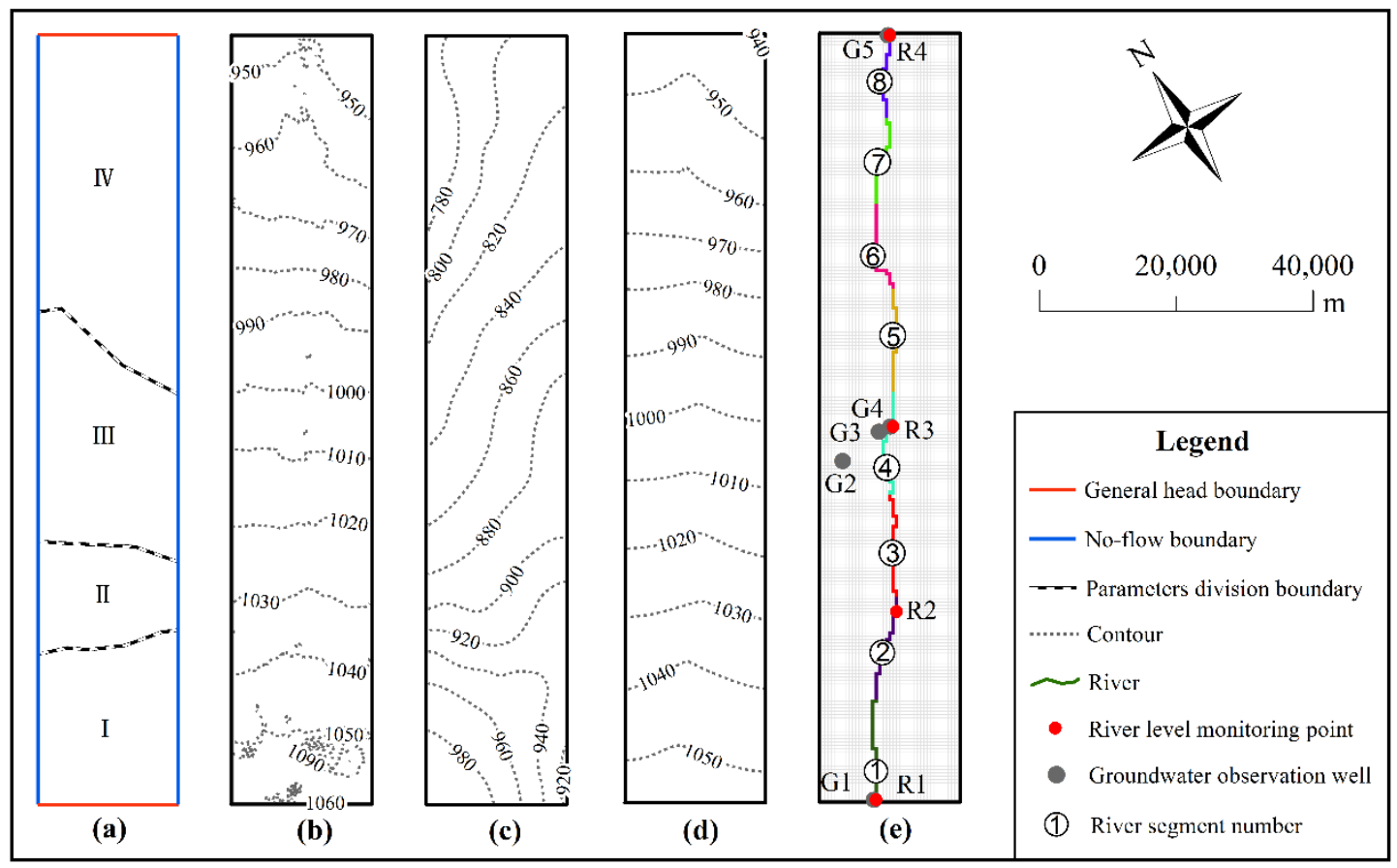

Figure 2. Model setup: (a) parameter division; (b) land surface elevation; (c) bottom elevation of the aquifer; (d) initial water levels; and (e) river segment division and monitoring sites. 


\subsubsection{Field Observations and Model Parameterization}

The daily groundwater levels were monitored at five observation wells (G1, G2, G3, G4, and G5) located along the riverbank (Figure 2e). The daily river water levels were also observed at wells R1, R2, R3, and R4, which were installed along the Donghe River (Figure 2e). The water levels were recorded by Schlumberger Mini-Diver pressure transducers (Eijkelcamp, EM Giesbeek, The Netherlands). The water level measurements compensated for barometric changes, which were measured by Schlumberger Baro-Divers. The uncertainty of the water level measurements was $\pm 5 \mathrm{~mm}$. In addition, the daily streamflow data at the LHS and daily E-601 pan evaporation rates at the Ejina meteorological station (Figure 1) were available for the period of 2010-2012.

Based on previous hydrogeological investigations [46] and numerical modelling [43], four aquifer zones with different hydraulic parameters were defined (Figure 2a, Table 1). The initial values of hydraulic conductivity varied from 6 to $21 \mathrm{~m} /$ day, and the initial specific yield was set to 0.15.

Table 1. Initial and calibrated values of the hydraulic conductivity $(K)$ and specific yield $\left(S_{y}\right)$ of the aquifer.

\begin{tabular}{|c|c|c|c|c|c|}
\hline \multirow{2}{*}{ Zone No. } & \multirow{2}{*}{ Dominant Material } & \multicolumn{2}{|c|}{ Initial Value } & \multicolumn{2}{|c|}{ Calibrated Value } \\
\hline & & $K, \mathrm{~m} / \mathrm{Day}$ & $S_{y},-$ & $K, \mathrm{~m} / \mathrm{Day}$ & $S_{y},-$ \\
\hline 1 & Coarse sand, gravel & 21 & 0.15 & 28 & 0.20 \\
\hline 2 & Coarse sand & 16 & 0.15 & 26 & 0.22 \\
\hline 3 & Medium sand & 11 & 0.15 & 23 & 0.17 \\
\hline 4 & Fine sand & 6 & 0.15 & 17 & 0.15 \\
\hline
\end{tabular}

Based on the riverbed hydraulic conductivities measured in previous studies $[13,16]$, we divided the Donghe River into eight segments, as shown in Figure 2. The parameters of each river segment, including the river width, thickness, and hydraulic conductivity, are listed in Table 2.

Table 2. River width $\left(L_{r}\right)$, riverbed $k_{0} / m_{0}$, and riverbed hydraulic conductance $(C)$ of the river segments.

\begin{tabular}{cccccc}
\hline \multirow{2}{*}{ River Segment No. } & \multirow{2}{*}{ Segment Length, $\mathbf{m}$} & \multirow{2}{*}{$\boldsymbol{L}_{\boldsymbol{r}}, \mathbf{m}$} & \multirow{2}{*}{$\boldsymbol{k}_{\mathbf{0}} / \mathbf{m}_{\mathbf{0}}, \mathbf{D a y}^{\mathbf{- 1}}$} & \multicolumn{2}{c}{$\boldsymbol{C}, \mathbf{~ m}^{\mathbf{2}} /$ Day } \\
\cline { 5 - 6 } & 16,000 & 140 & 0.50 & Initial & Calibrated \\
\hline 1 & 18,000 & 140 & 0.48 & 40,600 & $36,515-146,060$ \\
2 & 17,000 & 72 & 0.26 & 20,160 & $10,195-40,781$ \\
3 & 18,500 & 78 & 1.03 & 24,180 & $43,345-173,383$ \\
4 & 16,000 & 88 & 0.56 & 29,920 & $26,432-105,729$ \\
5 & 15,000 & 67 & 0.44 & 27,470 & $15,880-63,518$ \\
6 & 15,000 & 70 & 0.48 & 23,800 & $18,125-72,498$ \\
7 & 15,000 & 36 & 0.89 & 7200 & $17,261-69,045$ \\
\hline
\end{tabular}

\subsubsection{Numerical Simulations}

A three-dimensional finite difference-based groundwater flow model from MODFLOW-2005 [55] was used in the pre- and post-processing modelling environment of Processing MODFLOW [56] to simulate the saturated subsurface flow and surface water exchanges via the river-aquifer interface. In the present study, surface water leakage from the intermittent river was considered the main source of recharge for the aquifer [48]. The riverbed conductance $\left(C, \mathrm{~L}^{2} \mathrm{~T}^{-1}\right)$ is a key parameter that controls the interaction between the surface water and groundwater and is represented in MODFLOW [55,57] by the following equation:

$$
C=D_{\text {riv }} L_{r} k_{0} / m_{0}
$$

where $D_{\text {riv }}$ is the length of the river reach within the grid cell $(\mathrm{L}), L_{r}$ is the river width $(\mathrm{L}), m_{0}$ is the thickness of the riverbed $(\mathrm{L})$, and $k_{0}$ is the hydraulic conductivity of the riverbed $\left(\mathrm{LT}^{-1}\right)$. 
The Streamflow Routing (STR) package [58] was selected to simulate the interactions between the river water and groundwater. This package was able to simulate the major features of the surface water in this study, i.e., changes in the flow along the river due to interactions with groundwater. In the STR package, the flow in a stream is instantaneously routed downstream. The streamflow routing is designed through a network of streams and always flows in the same direction along the streams. The stream stages $\left(H_{r}, \mathrm{~L}\right)$ of a rectangular stream channel are calculated using Manning's equation as follows [56]:

$$
H_{r}=\left(\frac{Q \cdot n}{L_{r} \cdot S_{r i v}^{\frac{1}{2}}}\right)^{\frac{3}{5}}
$$

where $Q$ is the calculated river discharge $\left(\mathrm{L}^{3} / \mathrm{T}\right), S_{\text {riv }}$ is the slope of the river channel $(\mathrm{L} / \mathrm{L})$, and $n$ is Manning's roughness coefficient (-).

The amount of recharge from precipitation was insignificant, and the total precipitation over the period of 2010-2012 was only $91 \mathrm{~mm}$, based on observations at the local metrological station. For arid regions in north-western China, the direct recharging of rain-fed groundwater was estimated by the chloride mass balance method to be $1.5 \%$ of the mean annual precipitation $[59,60]$. In the study area, precipitation infiltration is most likely negligible, as indicated by the fact that single rainfall events of more than $5 \mathrm{~mm}$ were extremely rare between 2010 and 2012 and occurred predominantly during summer and autumn, when the potential evapotranspiration (PET) was extremely high (Figure 3). The PET was obtained from the water surface evaporation data observed by an E-601 evaporator at the local meteorological station (Figure 1) during the non-freezing period (April to October) and the calculated PET from Du, Yu, Wang, and Zhang [38] during the freezing period (November to the following March).
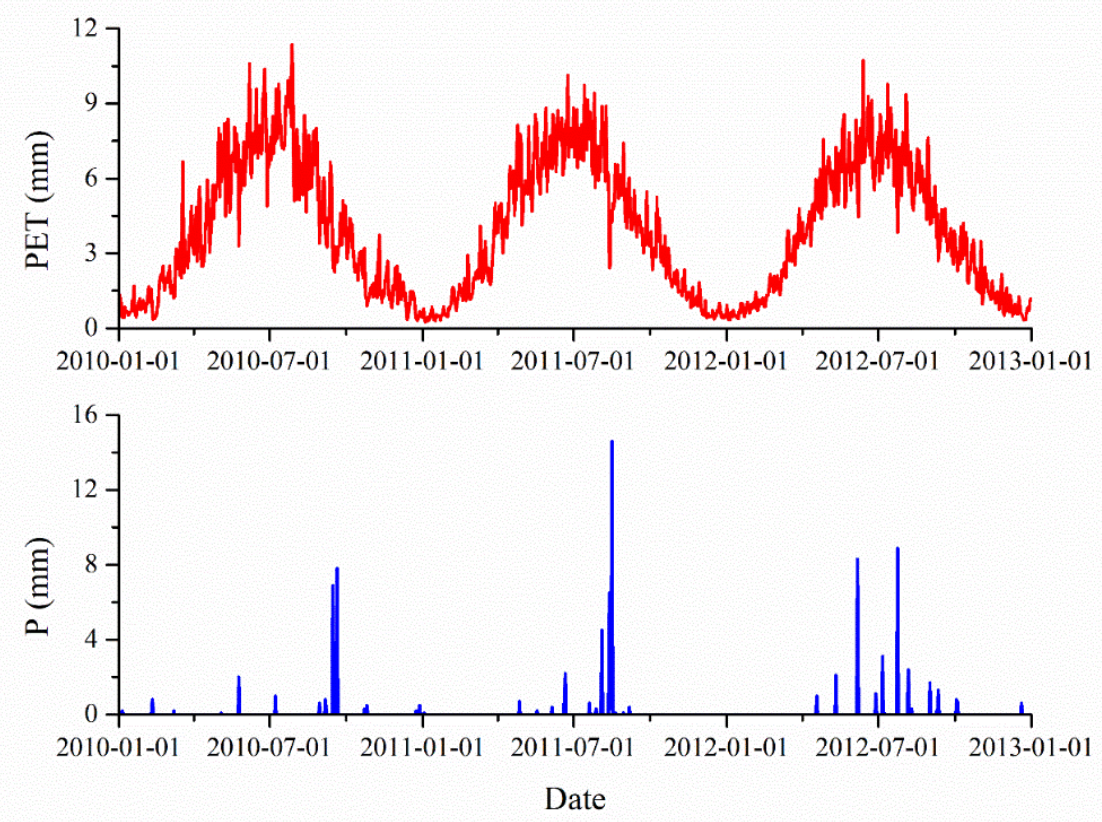

Figure 3. Daily potential evapotranspiration $(\mathrm{PET}, \mathrm{mm})$ and precipitation $(\mathrm{P}, \mathrm{mm})$ at the Ejina meteorological station.

Groundwater ET is a predominant discharge term in the water budget in the study area [39]. The depth of the water table in this area is mostly between 2 and $4 \mathrm{~m} \mathrm{[45];} \mathrm{therefore,} \mathrm{the} \mathrm{relationship}$ between ET and water table depth can be simply assumed to be linear [61] with an extinction depth of $5 \mathrm{~m}$ [62]. For this reason, the Evapotranspiration (EVT) package [55], which assumes a linear relationship between ET and water table depth, was used to simulate the processes of ET. As shown in Figure 1, excluding the dominant landscape of the Gobi Desert, there is a large area of riparian oasis 
within the model domain. To simulate plant transpiration in the riparian oasis and soil evaporation in the Gobi Desert, we assigned different maximum ET rates (ET max $)$ for these two landscape types. The monthly $E T_{\max }$ values for the riparian oasis and Gobi Desert were independently calibrated to match the linear relationship between ET and water table depth within the interval of 2-4 m, while the monthly variations followed the monthly measured and calculated PET rates at the Ejina meteorological station (Figure 3).

Groundwater extraction by pumping wells for agricultural irrigation occurs primarily in the southern and north-eastern areas of the study region (Figure 1). Based on field investigations, the farmland area irrigated by a single irrigation well was approximately $1.08 \times 10^{5} \mathrm{~m}^{2}$, and the daily water pumping rate of a farmland irrigation well was approximately $300 \mathrm{~m}^{3} /$ day during the irrigation period from May to August. The fraction of water returned to the aquifer as a result of agricultural irrigation was estimated to be approximately 0.1 [43]. Therefore, the water withdrawn from the aquifer for irrigation was $625 \mathrm{~m}^{3} /$ day within a grid cell of $2.50 \times 10^{5} \mathrm{~m}^{2}$. The Well package implemented in MODFLOW-2005 [55] was used to simulate this groundwater withdrawal from the aquifer. The total number of cells containing irrigation wells within the simulation domain was 182.

Previous studies indicated that vertical unsaturated flow is insignificant in the Gobi Desert based on the water exchange between rivers and aquifers $[63,64]$. In addition, the dominant vegetation in the riparian area comprises groundwater-dependent species (e.g., Populus and Tamarix), which mostly use groundwater for transpiration [50]. Therefore, unsaturated flow in the study area can be neglected and was not addressed in the simulations.

The numerical model consisted of 225 rows and 41 columns, with a total simulation domain of $112.5 \times 20.5 \mathrm{~km}$. The simulation period was from 21 April 2010 to 7 September 2012, and the temporal resolution was 1 day. We used the measured daily river flow at the LHS from 1 January to 21 April 2010 and ran the model to obtain the initial groundwater levels. The simulated groundwater levels on 21 April 2010 were set as the initial groundwater levels (Figure 2).

\subsubsection{Model Calibration}

We used the combination of the measured river water (R1-R4) and groundwater (G1-G5) levels to calibrate the hydraulic conductivity, specific yield of the aquifer, riverbed hydraulic conductance, and GHB hydraulic conductance. The root mean squared error (RMSE, $\mathrm{m}$ ) and correlation coefficient $(R)$ were used to evaluate the goodness of fit of the observed and calculated levels [65]. The calibrated parameters of the aquifer and streambed are listed in Tables 1 and 2, respectively. Notably, the river in this study is intermittent with a wide riverbed, and the river width is highly dependent on the river stage. To account for the influence of the river width on the river-aquifer exchange, we used the temporal variations in the riverbed hydraulic conductance (see Table 2) associated with each river flow event in the simulations. In addition, the GHB hydraulic conductance was also calibrated, with values of $2000 \mathrm{~m}^{2} /$ day for the southern boundary and $2200 \mathrm{~m}^{2} /$ day for the northern boundary.

As shown in Figure 4, the simulated and observed water levels at the nine monitoring wells are generally consistent. The simulated water levels reflect the variations in the water levels at the observation points. The differences between the calculated and observed water levels are less than $0.5 \mathrm{~m}$. The RMSE varies from 0.04 to 0.31 , depending on the observation well. The correlation coefficients between the simulated and observed water levels at most monitoring wells are relatively high (0.77-0.95), with the exception of that at well G2, where no correlation is observed. This finding can be explained by the relatively large distance of well G2 from the Donghe River (Figure 2). Thus, the groundwater level at well G2 is less affected by the fluctuations in the river water level compared to the levels at the other monitoring wells, which are located closer to the river. The slight seasonal variations in the groundwater level at well G2 are more likely affected by the ET process. Subsequent research should aim to address simulating ET processes using a nonlinear relationship between $E T_{\text {max }}$ and the groundwater level depth (e.g., [61,62]) to enhance the conformity of the observed and calculated levels in areas far from rivers. 


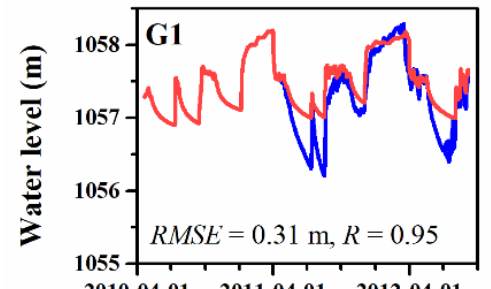

2010-04-01 2011-04-01 2012-04-01
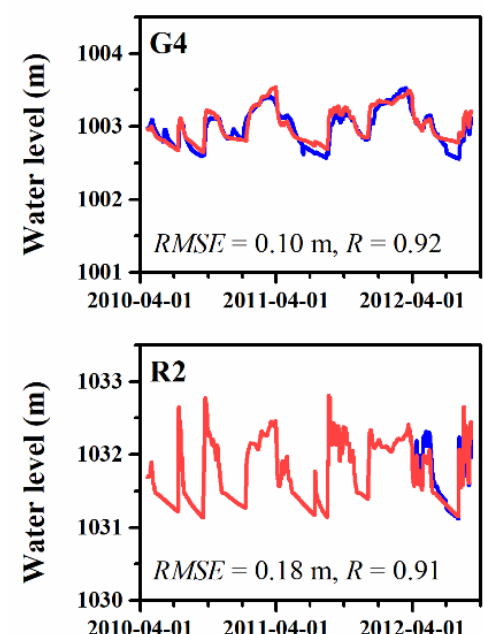

Date
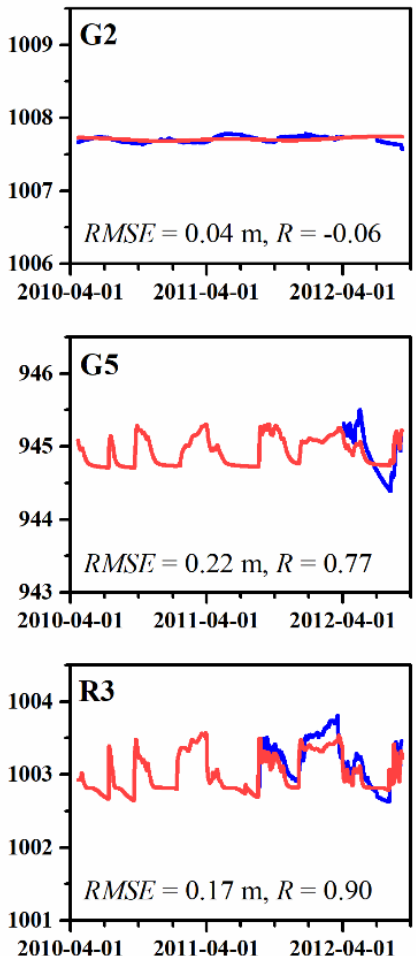

Date
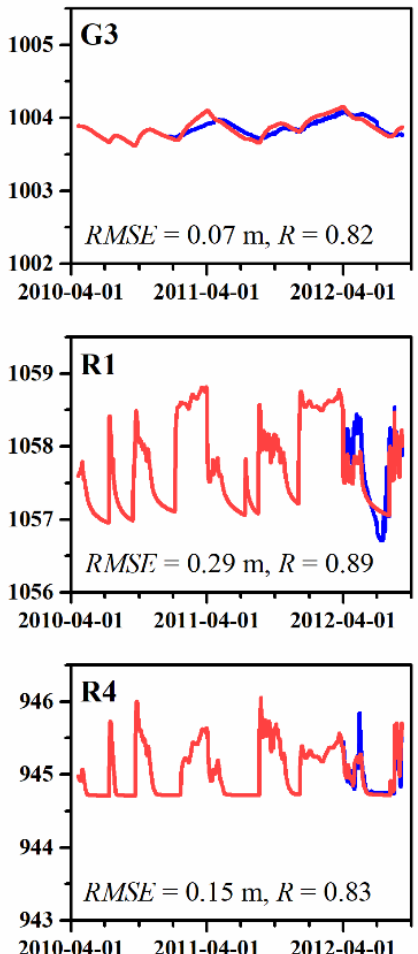

Date

Figure 4. Simulated versus observed water levels from 21 April 2010 to 7 September 2012.

\section{Results}

\subsection{Groundwater Budget}

During the period from 21 April 2010 to 7 September 2012, the total groundwater recharge within the simulated region was $4.26 \times 10^{8} \mathrm{~m}^{3}$. The river leakage through the streambed to the aquifer was $3.59 \times 10^{8} \mathrm{~m}^{3}$, which accounted for approximately $84 \%$ of the total groundwater recharge. The other $16 \%$ of the groundwater recharge was due to lateral flow through the southern and northern model boundaries $\left(6.77 \times 10^{7} \mathrm{~m}^{3}\right)$, which can be evidenced by hydro-geochemical analyses $[48,54]$ and regional groundwater flow simulations [42].

The total groundwater discharge within the simulated region was $2.8 \times 10^{8} \mathrm{~m}^{3}$, and the groundwater ET was $1.64 \times 10^{8} \mathrm{~m}^{3}$, which accounted for $59 \%$ of the total discharge. Groundwater discharge to the river $\left(5.53 \times 10^{7} \mathrm{~m}^{3}\right)$, groundwater exploitation $\left(4.19 \times 10^{7} \mathrm{~m}^{3}\right)$, and water outflow through the southern and northern model boundaries $\left(1.85 \times 10^{7} \mathrm{~m}^{3}\right)$ accounted for approximately $20 \%, 15 \%$, and $6 \%$ of the total discharge, respectively.

The groundwater budget analysis indicated that river water leakage was the main recharge source, and that groundwater ET was the predominant discharge type (Table 3). As noted by Wang et al. [66] and Wang et al. [67], these two processes determine the changes in water storage and control the spatial and temporal dynamics of the studied groundwater system. The difference between the total recharge and discharge $\left(1.46 \times 10^{8} \mathrm{~m}^{3}\right)$ can be explained by the increased groundwater storage in the model domain from 21 April 2010 to 7 September 2012. These results were consistent with previous studies (e.g., [39,45]), which demonstrated that, especially in the riparian zone, the groundwater level increased as a result of environmental flow controls aimed at delivering a set amount of surface water to the study area after 2000 . 
Table 3. Groundwater budget of the model domain from 21 April 2010 to 7 September 2012.

\begin{tabular}{cccccc}
\hline \multirow{2}{*}{ No. } & \multirow{2}{*}{ Budget Component } & \multicolumn{2}{c}{ Recharge } & \multicolumn{2}{c}{ Discharge } \\
\cline { 3 - 6 } & & Volume, $\mathbf{~ m}^{\mathbf{3}}$ & $\mathbf{\%}$ & Volume, $^{\mathbf{3}}$ & $\mathbf{\%}$ \\
\hline 1 & Water exchange with river & $3.59 \times 10^{8}$ & 84 & $5.53 \times 10^{7}$ & 20 \\
2 & Evapotranspiration & - & - & $1.64 \times 10^{8}$ & 59 \\
3 & Groundwater exploitation & - & & $4.19 \times 10^{7}$ & 15 \\
4 & Lateral flow & $6.77 \times 10^{7}$ & 16 & $1.85 \times 10^{7}$ & 6 \\
5 & Total & $4.26 \times 10^{8}$ & 100 & $2.80 \times 10^{8}$ & 100 \\
\hline
\end{tabular}

As shown in Figure 1, oasis area accounts for approximately $20 \%$ of the total simulation area, and the other 80\% represents the Gobi Desert, where groundwater ET processes are negligible [63]. The growing season lasts from May to September and accounts for approximately 150 days per year. As a result, the average ET rate in the oasis area during the growing season is approximately $0.79 \mathrm{~mm} /$ day, which is close to Tamarix's ET rate of $0.63-0.73 \mathrm{~mm} /$ day, as estimated using water table fluctuation methods during the growing seasons of 2010-2012 in this area [68].

\subsection{Daily River Leakage}

Daily river leakage through the streambed was highly dependent on river inflow, and river leakage generally followed river runoff processes (Figure 5). As shown in Figure 5, after high-flow events, e.g., from 18 August 2011 to 3 November 2011, the river leakage through the streambed was negative, which indicated that groundwater was discharged to the river. This finding can be explained by the fact that the riverbank stored surface water during the high stage, and when the river flow decreased rapidly, the groundwater stored in the riverbank was released into the river channel.

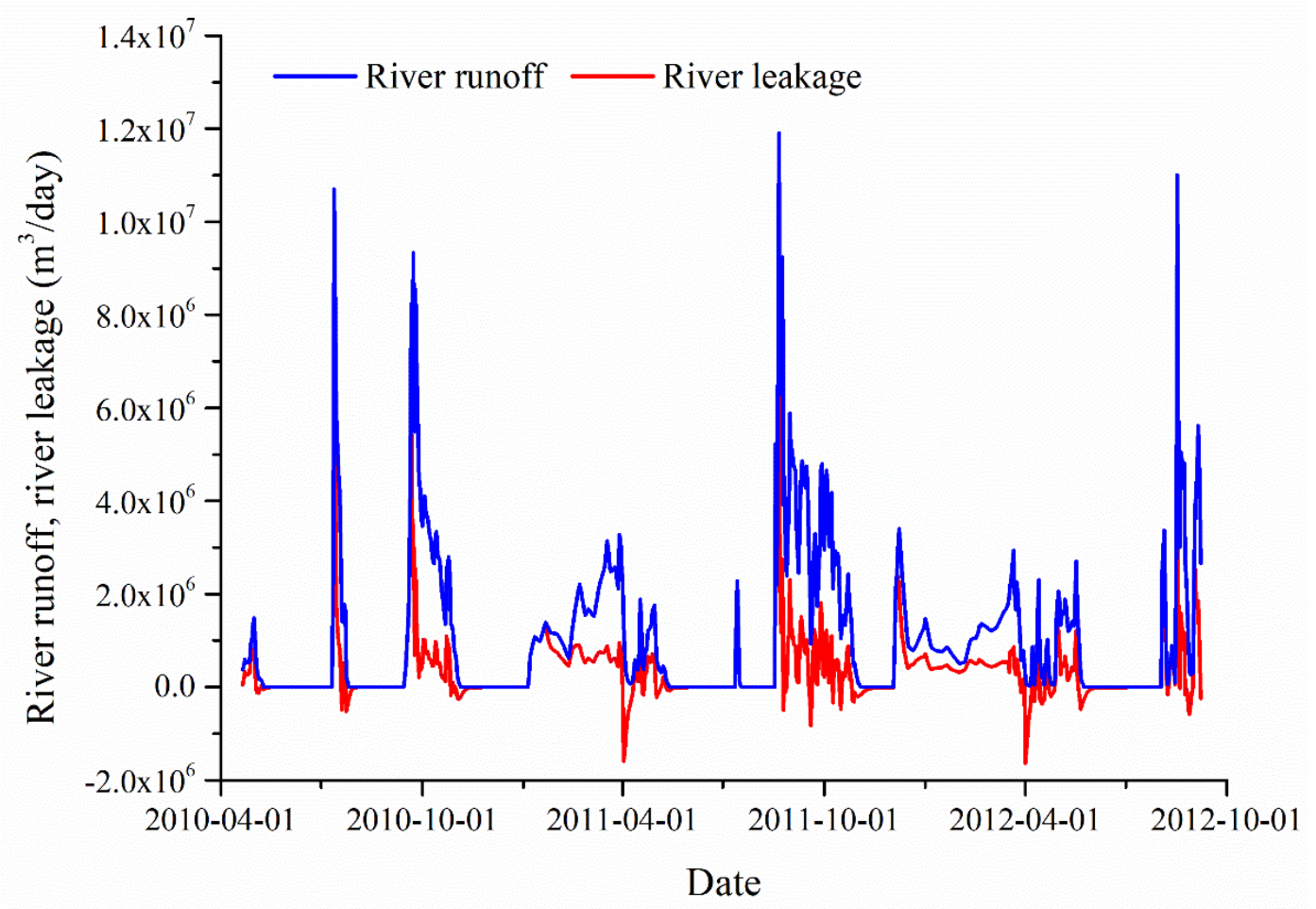

Figure 5. Observed daily runoff of the Donghe River at the LHS and simulated daily river leakage from 21 April 2010 to 7 September 2012.

As the total runoff of the Donghe River at the LHS was $9.19 \times 10^{8} \mathrm{~m}^{3}$, the river leakage rate, i.e., the percentage of river leakage divided by the total inflow, in the river reaches from the LHS to the 
Angcizha was approximately 33\% from 21 April 2010 to 7 September 2012. However, the average leakage rates during the eight individual flow events varied significantly from $24 \%$ to $99.8 \%$ (Table 4 ).

Table 4. Leakage rates of the river flow periods during the simulation period; correlation coefficients indicate relationships between the stream runoff and river leakage.

\begin{tabular}{|c|c|c|c|c|c|}
\hline River Flow Period & $\begin{array}{l}\text { Total Runoff } \\
\qquad\left(10^{6} \mathrm{~m}^{3}\right)\end{array}$ & $\begin{array}{c}\text { Average River } \\
\text { Discharge }\left(\mathrm{m}^{3} / \mathrm{s}\right)\end{array}$ & $\begin{array}{l}\text { River Leakage } \\
\qquad\left(10^{6} \mathrm{~m}^{3}\right)\end{array}$ & $\begin{array}{c}\text { River Leakage } \\
\text { Rate }(\%)\end{array}$ & $\begin{array}{l}\text { Correlation } \\
\text { Coefficient (-) }\end{array}$ \\
\hline 21 April-9 May 2010 & 11.0 & 6.7 & 4.6 & 42 & 0.85 \\
\hline 15 September-4 November 2010 & 154.1 & 35.0 & 43.4 & 28 & 0.52 \\
\hline 6 January-13 May 2011 & 166.8 & 15.1 & 65.5 & 39 & 0.25 \\
\hline 18 August-3 November 2011 & 248.7 & 36.9 & 59.1 & 24 & 0.60 \\
\hline 4 December 2011-24 May 2012 & 192.0 & 12.8 & 73 & 38 & 0.61 \\
\hline 3 August-7 September 2012 & 91.5 & 29.4 & 36.2 & 40 & 0.57 \\
\hline
\end{tabular}

For events with short-term flow durations (e.g., from 21 April to 9 May 2010 and 13 to 17 July 2011), the river leakage rates were relatively high, with values of $42-99.8 \%$. In contrast, for events with long-term flow durations (e.g., from 18 August to 3 November 2011 and 4 December 2011 to 24 May 2012), the river leakage rates were relatively low, with values of $24-38 \%$. This difference is mainly associated with the decreasing hydraulic gradient between the surface water and groundwater during events with long-term flow durations.

Table 4 shows the correlation coefficients between the stream leakage and river runoff for eight individual flow events. These correlation coefficients are relatively high (from 0.52 to nearly 1 , except for the flow event from 6 January to 13 May 2011 with a value of 0.25). In addition, there is a common tendency that shorter flow events during summer periods exhibit higher correlations. For example, short flow events, e.g., 13-17 July 2011, 21 April-9 May 2010, and 12-26 July 2010, have correlation coefficients of 0.79-0.99, while relatively long flow events, e.g., 6 January-13 May 2011, 3 August-7 September 2012, and 4 December 2011-24 May 2012, have correlation coefficients of 0.25-0.61. Therefore, it can be stated that if water needs to be transported from Langxinshan to terminal lakes with minimum leakage, the water should be transported during winter periods. However, to increase the groundwater level in the riparian zone and support riparian ecosystems, it is better to transport water predominantly during spring and summer periods.

From the perspective of ground and surface water interactions, the interaction regime is constantly connected, which means that even after continuous periods without runoff (for example, from April to June), the groundwater level remains above the bottom of the riverbed sediments. Thus, water from the stream percolates via saturated sediments, which contributes to relatively high leakage rates.

\subsection{Parameter Sensitivity Analysis}

To investigate the influence of the model parameters on the simulation results, an uncertainty analysis was conducted. The present study revealed the model sensitivity by analyzing the effects of the ET rate, aquifer parameters, and streambed parameters on the cumulative river leakage.

Sensitivity represents the effect of variations in one parameter on the calculation results and is generally represented by the following equation [69]:

$$
\beta_{k}=\frac{\Delta Q}{\Delta \alpha_{k}} \approx \frac{Q\left(\alpha_{k}+\Delta \alpha_{k}\right)-Q\left(\alpha_{k}\right)}{\Delta \alpha_{k}}
$$

where $\beta_{k}$ represents the sensitivity of the model variable (leakage $(Q)$ in the present study) to the parameter, $\alpha_{k}$ represents the actual parameter value, $\Delta \alpha_{k}$ represents the change in the parameter value, 
$Q\left(\alpha_{k}+\Delta \alpha_{k}\right)$ represents the leakage simulated by the model after the parameter variation and $Q\left(\alpha_{k}\right)$ represents the leakage simulated by the model before the parameter variation.

A local sensitivity analysis method was used to analyze the sensitivity of the model parameters to river leakage. Specifically, we changed the hydraulic conductivity $(K)$ and specific yield $\left(S_{y}\right)$ of the aquifer, the maximum ET rate $\left(E T_{\max }\right)$, and the riverbed conductance $(C)$ by $-20 \%$ to $20 \%$. The parameter range selected for the sensitivity analysis was based on in situ experiments of streambed hydraulic conductivity $[13,16]$ and the observed potential evaporation in the study area (Figure 3 ). Only one parameter was changed each time to determine the leakage variation (Figure 6). The results of the sensitivity analysis showed that the hydraulic conductivity of the aquifer had the greatest effect on leakage. When the hydraulic conductivity changed by $20 \%$, the leakage changed by approximately $11 \%$. Thus, the sensitivity of leakage to the hydraulic conductivity of the aquifer was 0.57 . The calculations indicated that the sensitivities of leakage to the maximum ET rate, specific yield, and riverbed conductance were $0.28,0.08$, and 0.02 , respectively. Therefore, leakage was most sensitive to the hydraulic conductivity of the aquifer, followed by the maximum ET rate, specific yield of the aquifer, and riverbed conductance.

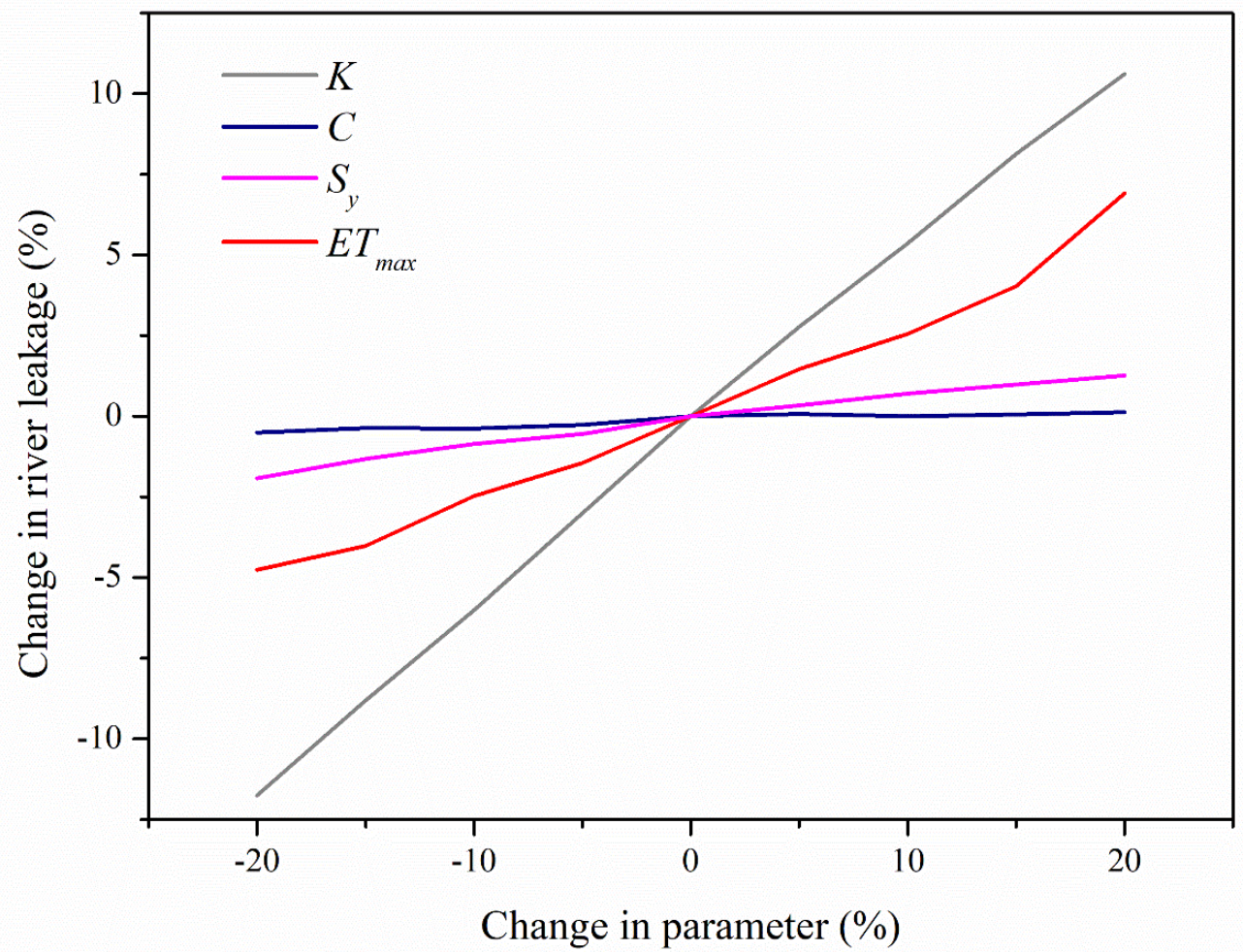

Figure 6. Sensitivity of river leakage to the model parameters.

The significant sensitivity of the river leakage to the maximum ET rate can be explained by the increase in the hydraulic gradient between the surface and groundwater when $E T_{\max }$ rises, which causes a decline in the groundwater level. Figure 7 demonstrates that if we enhance $E T_{\max }$, the hydraulic gradient rises, causing the leakage rate from the river to increase. Thus, according to the simulation results, riverbank recharge processes are highly dependent on riparian ET processes. 

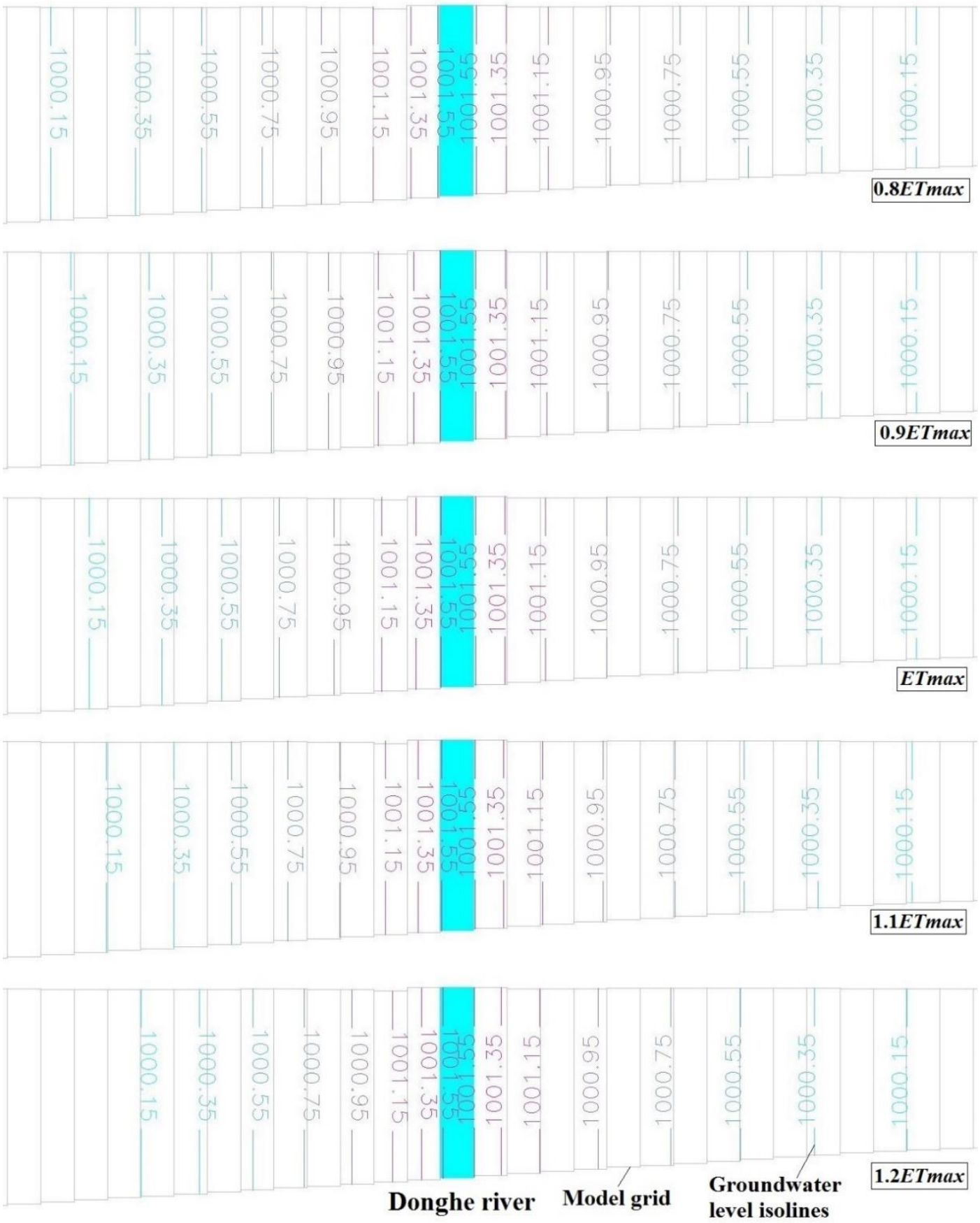

Figure 7. Groundwater levels under different values of the maximum evapotranspiration rate (cross-section from west to east in the middle of the simulated area).

\section{Discussion}

To explain the high sensitivity of river losses to groundwater ET in the riparian area, we consider a supporting analytical model for the formation of groundwater flow from the river towards the ET zone in the riparian area adjacent to the river channel. For this purpose, let us consider the one-dimensional groundwater flow formed by losses from the river and discharged by the ET of groundwater in the adjacent riparian zone. The details of the formulation of the corresponding groundwater flow boundary problem are given in Appendix A. As shown in Appendix A, water losses from the river during stationary groundwater flow periods are controlled by two hydraulic parameters expressed in length units. The first parameter, which is the streambed hydraulic resistance length, $\Delta L$, characterizes 
the additional hydraulic resistance due to the bottom sediments of the river channel [36]. The length $\Delta L$ is expressed as follows:

$$
\Delta L=b_{r}^{-1} \operatorname{coth}\left(0.5 L_{r} b_{r}\right) ; b_{r}=\sqrt{\frac{k_{0}}{m_{0} T}}
$$

The second parameter is the characteristic width, $L_{E T}$, of the groundwater ET zone adjacent to the river channel. This length depends on the parameters characterizing the decrease in ET with the depth of the groundwater table and is expressed as follows:

$$
L_{E T}=\sqrt{\frac{d_{\max } T}{E T_{\max }}} ; d_{\max }=Z_{\text {surf }}-Z_{\text {crit }}
$$

The expression for the specific flow rate of losses from the river, $q$, to the riparian area is as follows:

$$
q=2 T \frac{H_{r}-Z_{c r i t}}{L_{E T}+\Delta L}=2 T \frac{H_{r}-Z_{c r i t}}{L_{E T}\left(1+\alpha_{r}\right)} ; \alpha_{r}=\sqrt{\frac{E T_{\max } m_{0}}{d_{\max } k_{0}}} \operatorname{coth}\left(0.5 L_{r} b_{r}\right)
$$

The factor of 2 in Equation (6) assumes that there will be symmetrical losses to both riverbanks with riparian zones. The notations for Equations (4)-(6) are listed in the Appendix A.

The equations shown above help to clarify the fact that the sensitivity of leakage to riverbed conductance is only 0.02 , while that to the hydraulic conductivity of the aquifer is 0.57 , which can be explained by the value of the streambed hydraulic resistance length $(\Delta L)$, which is between 60 and 80 $\mathrm{m}$, depending on the number of river segments (Table 2). The parameter $\Delta L$ characterizes the hydraulic resistance of the bottom sediments (Appendix A). In the study area, the hydraulic conductivity of the riverbed sediments is relatively high, i.e., 1-40 m/day [41], which leads to relatively small bottom sediment hydraulic resistance values.

In addition, an analytical criterion, $\alpha_{r}$ (Appendix A), can be calculated using typical values of $E T_{\max }$ during the vegetation period as a function of $k_{0}, m_{0}$, and $d_{\max }$ (extinction depth). The calculated value of $\alpha_{r}$ is 0.01 , which indicates almost no sensitivity of leakage to the streambed hydraulic conductance. However, the sensitivities of leakage to the hydraulic conductivity of the aquifer and $E T_{\max }$ are comparable. Thus, under the present conditions, river leakage is more sensitive to the hydraulic parameters related to the aquifer and ET rather than to the riverbed, and thus, it is more important to study aquifer parameters and ET parameters to accurately estimate river leakage from such intermittent streams under arid conditions. The present conclusion is valid for cases with high maximum ET rate values and relatively low $\Delta L$ values.

Equally important is that the EVT package [55] selected in this study to simulate ET processes is oversimplified and is highly based on previous empirical analysis of the dependence of ET on the water table depth between 2 and $4 \mathrm{~m}[45,68]$. This approach is probably acceptable for analyses of surface-groundwater exchanges at regional scales. However, to address riparian ET processes, nonlinear ET models that account for plant types with different rooting depths (e.g., [70]), or even physical-based models with dynamic root optimization schemes (e.g., [71]), are required.

\section{Conclusions}

The present study conducted coupled simulations of surface water and groundwater exchanges in an arid ephemeral stream-aquifer system using the MODFLOW-2005 code with the STR package. The results showed that from 21 April 2010 to 7 September 2012, river water leakage accounted for 33\% of the total river runoff for the simulated segments.

A sensitivity analysis demonstrated that the most important parameters of the studied system that influence river leakage are the hydraulic conductance of the aquifer and the maximum ET rate. Almost no sensitivity was obtained for the riverbed hydraulic conductance, which was explained by the relatively high hydraulic conductivity of the riverbed sediments. Thus, instead of studying 
the hydraulic parameters of riverbeds, further research should focus on studying the ET parameters and selecting an appropriate ET model that reflects the eco-physiology of riparian ecosystems [70]. The present conclusion is valid only for cases with relatively high streambed hydraulic conductivities (compared to the hydraulic conductivity of the aquifer) in arid regions, as demonstrated in the studied case. Coupled surface/groundwater models, which are used to estimate river leakage, should consider riparian zones because they play a dominant role in the formation of leakage from rivers for recharging via ET.

As the model synchronously simulated the daily variation in the river water and groundwater levels that affected leakage, the simulation results are more reliable than those of previous models that used only groundwater level data collected over long periods for verification when simulating leakage (temporal resolution greater than 10 days). To the best of our knowledge, the present study is the first to simulate and analyze the daily river leakage process under the conditions of ecological water transport in the downstream region of the Heihe River. The study results can provide scientific evidence for further ecological water transport research.

Author Contributions: Conceptualization, J.Y., P.W., and S.P.P.; methodology, L.M., P.Y.V., and S.P.P.; validation, P.W.; data curation, L.M. and P.W.; writing—original draft preparation, L.M., and P.W.; writing-review and editing, P.Y.V., P.W., and S.P.P.; supervision, J.Y.; and funding acquisition, P.W., J.Y., P.Y.V., and S.P.P. All authors have read and agreed to the published version of the manuscript.

Funding: This research was supported by grants from the National Natural Science Foundation of China (Nos. 41671023 and 41877165) and the NSFC-RFBR Programme 2018-2019 (Nos. 41811530084 and 18-55-53025 ГФЕН_a), and the second author was supported by the Russian Foundation for Basic Research (No. 19-35-90014 Аспиранты).

Acknowledgments: We would like to thank Grinevsky Sergey of the Department of Hydrogeology, Lomonosov Moscow State University, for his helpful advice and Juntao Zhu, Yongliang Xu, Zhiyong Wang, and Dandan Wang for their participation in the fieldwork. Ping Wang and Sergey P. Pozdniakov are grateful for support from the Special Exchange Program of the Chinese Academy of Sciences 2019-2020. The authors also gratefully acknowledge the anonymous reviewers for their valuable comments and suggestions that have led to substantial improvements over an earlier version of the manuscript.

Conflicts of Interest: The authors declare no conflicts of interest.

\section{Appendix A}

Groundwater flow from a river to a riparian evapotranspiration (ET) zone.

In an arid region with a groundwater ET zone located along a stream in summer (Figure A1), river water infiltrates the aquifer. This water is discharged within the riparian zone with shallow groundwater levels. Consider the situation shown in Figure A1, and suppose that the groundwater flow consists of two zones.

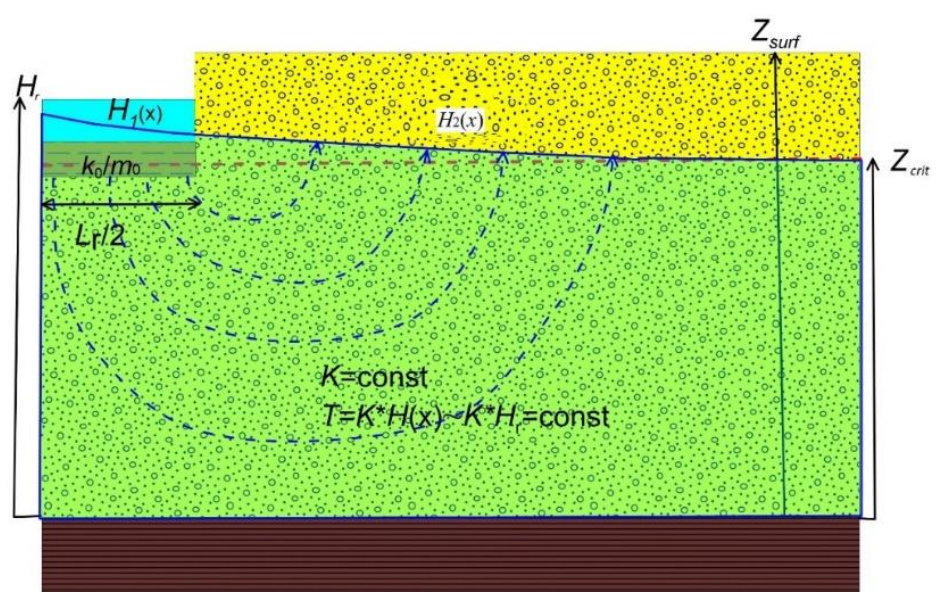

Figure A1. Schematic flow of groundwater discharge in an evapotranspiration (ET) zone located along a stream. 
Zone 1 is the zone below the stream. In this zone, the surface-groundwater exchange rate, $v_{z}(x)$, is proportional to the head difference between the river, $H_{r}$, and groundwater, $H_{1}(x)$, as well as the hydraulic resistance of bottom sediments as follows:

$$
v_{z}(x)=\frac{k_{0}}{m_{0}}\left(H_{r}-H_{1}(x)\right)
$$

where $k_{0}$ and $m_{0}$ are the hydraulic conductivity and the thickness of the bottom sediments, respectively, and $x$ is the distance perpendicular to the river direction.

In the next zone, zone 2, the rate of groundwater discharge $E T_{g w}(x)$ can be described as a linear function of the groundwater depth as follows:

$$
E T_{g w}(x)=E T_{\max }\left(\frac{Z_{\text {surf }}-H_{2}(x)}{d_{\max }}\right), 0 \leq Z_{\text {surf }}-H_{2}(x) \leq d_{\text {max }}
$$

where $E T_{\max }$ is the PET and $d_{\max }$ is the groundwater ET extinction depth.

Let us consider a steady-state groundwater flow such that the groundwater recharge from the river is balanced by the groundwater ET. Using the Dupuit precondition regarding the head hydrostatic distribution of the aquifer saturated thickness and constant transmissivity, we can express the following system of 1D steady-state equations for the groundwater flow:

$$
\begin{gathered}
\frac{d^{2} H_{1}}{d x^{2}}-b_{r}^{2}\left(H_{1}-H_{r}\right)=0, \frac{d^{2} H_{2}}{d x^{2}}-b_{E T}^{2}\left(H_{2}-H_{c r i t}\right)=0, b_{r}=\sqrt{\frac{k_{0}}{m_{0} T}} ; b_{E T}=\sqrt{\frac{E T_{\max }}{d_{\max } T}} \\
d_{\max }=Z_{\text {surf }}-Z_{\text {crit }},
\end{gathered}
$$

where $T$ is the transmissivity of the aquifer, and $Z_{c r i t}$ is the absolute position of the groundwater ET extinction depth.

The boundary conditions for this system assume symmetry of flow in the middle of the river and equality of heads and gradients at the boundaries of the zones as follows:

$$
\begin{aligned}
& x=0: \frac{d H_{1}}{d x}=0 \\
& x=\frac{1}{2} L_{r}: H_{1}=H_{2} ; \frac{d H_{1}}{d x}=\frac{d H_{2}}{d x} \\
& X \rightarrow \infty: H_{2}=Z_{\text {crit }}
\end{aligned}
$$

The general solution of system (Equation (A3)) is:

$$
\begin{gathered}
H_{r}-H_{1}(x)=C_{1} \exp \left(-b_{r} x\right)+C_{2} \exp \left(b_{r} x\right) \\
H_{2}(x)-Z_{c r i t}=C_{3} \exp \left(-b_{e} x\right)+C_{4} \exp \left(b_{e} x\right)
\end{gathered}
$$

The unknown coefficients can be determined using (Equation (A4)) as follows:

$$
\begin{aligned}
& H_{1}(x)=H_{r}-\left(H_{r}-Z_{c r i t}\right) b_{E T} \frac{\cosh \left(b_{r} x\right)}{b_{E T} \cosh \left(0.5 L_{r} b_{r}\right)+b_{r} \sinh \left(0.5 L_{r} b_{r}\right)} \\
& H_{2}(x)=Z_{c r i t}+\left(H_{r}-Z_{c r i t}\right) b_{r} \frac{\exp \left(-b_{E T} x\right)}{\exp \left(-0.5 L_{r} b_{E T}\right)} \frac{\sinh \left(0.5 L_{r} b_{r}\right)}{b_{E T} \cosh \left(0.5 L_{r} b_{r}\right)+b_{r} \sinh \left(0.5 L_{r} b_{r}\right)}
\end{aligned}
$$

Consider the specific flow $q$ from the river to the riparian zone as follows:

$$
\begin{gathered}
q=-\left.T \frac{d H_{1}}{d x}\right|_{x=0.5 L_{r}}=T \frac{H_{r}-Z_{c r i t}}{\Delta L+L_{E T}} \\
\Delta L=b_{r}^{-1} \operatorname{coth}\left(0.5 L_{r} b_{r}\right) ; L_{E T}=b_{E T}^{-1}
\end{gathered}
$$

For the more general case of a limited riparian zone with a width of $0.5 L_{0}$, note that (Equation (A7)) is also valid, although $L_{E T}$ should be calculated as follows:

$$
L_{E T}=b_{E T}^{-1} \operatorname{coth}\left(0.5 L_{0} b_{E T}\right)
$$


Thus, the groundwater flow from the river used for ET depends on two characteristic lengths. The first length, $\Delta L$, characterizes the hydraulic resistance of the bottom sediments. The second length, $L_{E T}$, characterizes the hydraulic resistance of the groundwater discharge due to evaporation, which changes linearly with the depth of the groundwater table. Thus, (Equation (A7)) can be rewritten as follows:

$$
q=T \frac{H_{r}-Z_{c r i t}}{L_{E T}\left(1+\alpha_{r}\right)} ; \alpha_{r}=\sqrt{\frac{E T_{\max } m_{0}}{d_{\max } k_{0}}} \operatorname{coth}\left(0.5 L_{r} b_{r}\right)
$$

For a small $\alpha_{r}\left(\alpha_{r}<0.1\right)$, the hydraulic resistance of the bottom sediments does not play an important role in the river water loss due to ET, while for a large $\alpha_{r}\left(\alpha_{r}>10\right)$, the losses of river water due to ET are controlled by the hydraulic resistance of the bottom sediments.

\section{References}

1. Wang, P. Progress and prospect of research on water exchange between intermittent rivers and aquifers in arid regions of northwestern China. Prog. Geogr. 2018, 37, 183-197, (In Chinese with English abstract).

2. Datry, T.; Larned, S.T.; Tockner, K. Intermittent Rivers: A Challenge for Freshwater Ecology. BioScience 2014, 64, 229-235. [CrossRef]

3. Sophocleous, M. Interactions between groundwater and surface water: The state of the science. Hydrogeol. J. 2002, 10, 52-67. [CrossRef]

4. Brunner, P.; Therrien, R.; Renard, P.; Simmons, C.T.; Franssen, H.-J.H. Advances in understanding river-groundwater interactions. Rev. Geophys. 2017, 55, 818-854. [CrossRef]

5. Filimonova, E.A.; Baldenkov, M.G. A combined-water-system approach for tackling water scarcity: Application to the Permilovo groundwater basin, Russia. Hydrogeol. J. 2016, 24, 489-502. [CrossRef]

6. Pekel, J.-F.; Cottam, A.; Gorelick, N.; Belward, A.S. High-resolution mapping of global surface water and its long-term changes. Nature 2016, 540, 418. [CrossRef]

7. Partington, D.; Therrien, R.; Simmons, C.T.; Brunner, P. Blueprint for a coupled model of sedimentology, hydrology, and hydrogeology in streambeds. Rev. Geophys. 2017, 55, 287-309. [CrossRef]

8. Constantz, J. Streambeds merit recognition as a scientific discipline. Wiley Interdiscip. Rev. Water 2016, 3, 13-18. [CrossRef]

9. Filimonova, E.; Shtengelov, R. The dependence of stream depletion by seasonal pumping on various hydraulic characteristics and engineering factors. Hydrogeol. J. 2013, 21, 1821-1832. [CrossRef]

10. Song, J.; Chen, X.; Cheng, C.; Summerside, S.; Wen, F. Effects of hyporheic processes on streambed vertical hydraulic conductivity in three rivers of Nebraska. Geophys. Res. Lett. 2007, 34, L07409. [CrossRef]

11. Xian, Y.; Jin, M.; Zhan, H. Buffer effect on identifying transient streambed hydraulic conductivity with inversion of flood wave responses. J. Hydrol. 2020, 580, 124261. [CrossRef]

12. Tang, Q.; Kurtz, W.; Schilling, O.S.; Brunner, P.; Vereecken, H.; Hendricks Franssen, H.J. The influence of riverbed heterogeneity patterns on river-aquifer exchange fluxes under different connection regimes. $J$. Hydrol. 2017, 554, 383-396. [CrossRef]

13. Min, L.; Yu, J.; Liu, C.; Zhu, J.; Wang, P. The spatial variability of streambed vertical hydraulic conductivity in an intermittent river, northwestern China. Environ. Earth Sci. 2013, 69, 873-883. [CrossRef]

14. Chen, X.; Song, J.; Wang, W. Spatial variability of specific yield and vertical hydraulic conductivity in a highly permeable alluvial aquifer. J. Hydrol. 2010, 388, 379-388. [CrossRef]

15. Wu, G.; Shu, L.; Lu, C.; Chen, X.; Zhang, X.; Appiah-Adjei, E.; Zhu, J. Variations of streambed vertical hydraulic conductivity before and after a flood season. Hydrogeol. J. 2015, 23, 1603-1615. [CrossRef]

16. Wang, P.; Pozdniakov, S.P.; Vasilevskiy, P.Y. Estimating groundwater-ephemeral stream exchange in hyper-arid environments: Field experiments and numerical simulations. J. Hydrol. 2017, 555, 68-79. [CrossRef]

17. Hatch, C.E.; Fisher, A.T.; Revenaugh, J.S.; Constantz, J.; Ruehl, C. Quantifying surface water-groundwater interactions using time series analysis of streambed thermal records: Method development. Water Resour. Res. 2006, 42, W10410. [CrossRef]

18. Weber, M.D.; Booth, E.G.; Loheide, S.P. Dynamic ice formation in channels as a driver for stream-aquifer interactions. Geophys. Res. Lett. 2013, 40, 3408-3412. [CrossRef] 
19. Tooth, S. Process, form and change in dryland rivers: A review of recent research. Earth Sci. Rev. 2000, 51, 67-107. [CrossRef]

20. Xian, Y.; Jin, M.; Liu, Y.; Si, A. Impact of lateral flow on the transition from connected to disconnected stream-aquifer systems. J. Hydrol. 2017, 548, 353-367. [CrossRef]

21. Phogat, V.; Potter, N.J.; Cox, J.W.; Šimůnek, J. Long-Term Quantification of Stream-Aquifer Exchange in a Variably-Saturated Heterogeneous Environment. Water Resour. Manag. 2017, 31, 4353-4366. [CrossRef]

22. Brunner, P.; Cook, P.G.; Simmons, C.T. Disconnected Surface Water and Groundwater: From Theory to Practice. Ground Water 2011, 49, 460-467. [CrossRef]

23. Brunner, P.; Cook, P.G.; Simmons, C.T. Hydrogeologic controls on disconnection between surface water and groundwater. Water Resour. Res. 2009, 45, W01422. [CrossRef]

24. Cook, P.G. Quantifying river gain and loss at regional scales. J. Hydrol. 2015, 531 Pt 3, 749-758. [CrossRef]

25. Kalbus, E.; Reinstorf, F.; Schirmer, M. Measuring methods for groundwater-surface water interactions: A review. Hydrol. Earth Syst. Sci. 2006, 10, 873-887. [CrossRef]

26. Landon, M.K.; Rus, D.L.; Harvey, F.E. Comparison of instream methods for measuring hydraulic conductivity in sandy streambeds. Ground Water 2001, 39, 870-885. [CrossRef]

27. Shanafield, M.; Cook, P.G. Transmission losses, infiltration and groundwater recharge through ephemeral and intermittent streambeds: A review of applied methods. J. Hydrol. 2014, 511, 518-529. [CrossRef]

28. Pozdniakov, S.P.; Wang, P.; Lekhov, M.V. A semi-analytical generalized Hvorslev formula for estimating riverbed hydraulic conductivity with an open-ended standpipe permeameter. J. Hydrol. 2016, 540, 736-743. [CrossRef]

29. Caissie, D.; Luce, C.H. Quantifying streambed advection and conduction heat fluxes. Water Resour. Res. 2017, 53, 1595-1624. [CrossRef]

30. Zhou, D.; Zhang, Y.; Gianni, G.; Lichtner, P.; Engelhardt, I. Numerical modelling of stream-aquifer interaction: Quantifying the impact of transient streambed permeability and aquifer heterogeneity. Hydrol. Process. 2018, 32, 2279-2292. [CrossRef]

31. Rau, G.C.; Halloran, L.J.S.; Cuthbert, M.O.; Andersen, M.S.; Acworth, R.I.; Tellam, J.H. Characterising the dynamics of surface water-groundwater interactions in intermittent and ephemeral streams using streambed thermal signatures. Adv. Water Resour. 2017, 107, 354-369. [CrossRef]

32. Batlle-Aguilar, J.; Cook, P.G. Transient infiltration from ephemeral streams: A field experiment at the reach scale. Water Res. Res. 2012, 48, W11518. [CrossRef]

33. Niswonger, R.G.; Prudic, D.E.; Fogg, G.E.; Stonestrom, D.A.; Buckland, E.M. Method for estimating spatially variable seepage loss and hydraulic conductivity in intermittent and ephemeral streams. Water Resour. Res. 2008, 44, 1-14. [CrossRef]

34. Reid, M.E.; Dreiss, S.J. Modeling the effects of unsaturated, stratified sediments on groundwater recharge from intermittent streams. J. Hydrol. 1990, 114, 149-174. [CrossRef]

35. Leake, S.A.; Gungle, B. Evaluation of Simulations to Understand Effects of Groundwater Development and Artificial Recharge on the Surface Water and Riparian Vegetation Sierra Vista Subwatershed, Upper San Pedro Basin, Arizona; 2012-1206; U.S. Geological Survey: Reston, VA, USA, 2012.

36. Wang, P.; Pozdniakov, S.P.; Shestakov, V.M. Optimum experimental design of a monitoring network for parameter identification at riverbank well fields. J. Hydrol. 2015, 523, 531-541. [CrossRef]

37. Doppler, T.; Franssen, H.-J.H.; Kaiser, H.-P.; Kuhlman, U.; Stauffer, F. Field evidence of a dynamic leakage coefficient for modelling river-aquifer interactions. J. Hydrol. 2007, 347, 177-187. [CrossRef]

38. Du, C.; Yu, J.; Wang, P.; Zhang, Y. Reference Evapotranspiration Changes: Sensitivities to and Contributions of Meteorological Factors in the Heihe River Basin of Northwestern China (1961-2013; 2014). Adv. Meteorol. 2016, 2016, 4143580. [CrossRef]

39. Wang, P.; Yu, J.; Pozdniakov, S.P.; Grinevsky, S.O.; Liu, C. Shallow groundwater dynamics and its driving forces in extremely arid areas: A case study of the lower Heihe River in northwestern China. Hydrol. Process. 2014, 28, 1539-1553. [CrossRef]

40. Liu, X.; Yu, J.; Wang, P.; Zhang, Y.; Du, C. Lake Evaporation in a Hyper-Arid Environment, Northwest of China-Measurement and Estimation. Water 2016, 8, 527. [CrossRef]

41. Vasilevskiy, P.Y.; Wang, P.; Pozdniakov, S.P.; Davis, P. Revisiting the modified Hvorslev formula to account for the dynamic process of streambed clogging: Field validation. J. Hydrol. 2019, 568, 862-866. [CrossRef] 
42. Yao, Y.; Zheng, C.; Liu, J.; Cao, G.; Xiao, H.; Li, H.; Li, W. Conceptual and numerical models for groundwater flow in an arid inland river basin. Hydrol. Process. 2015, 29, 1480-1492. [CrossRef]

43. Xu, Y.; Yu, J.; Zhang, Y.; Wang, P.; Wang, D. Groundwater dynamic numerical simulation in the Ejina Oasis in an ecological water conveyance period. Hydrogeol. Eng. Geol. 2014, 41, 11-18, (In Chinese with English abstract).

44. Akiyama, T.; Sakai, A.; Yamazaki, Y.; Wang, G.; Fujita, K.; Nakawo, M.; Masayoshi, A.; Jurhpei, A.; Yuki, G. Surface water-groundwater interaction in the Heihe River basin, Northwestern China. Bull. Glaciol. Res. 2007, 24, 87-94.

45. Wang, P.; Yu, J.; Zhang, Y.; Fu, G.; Min, L.; Ao, F. Impacts of environmental flow controls on the water table and groundwater chemistry in the Ejina Delta, northwestern China. Environ. Earth Sci. 2011, 64, 15-24. [CrossRef]

46. Wu, X.; Shi, S.; Li, Z.; Hao, A.; Qiao, W.; Yu, Z.; Zhang, S. The study on the groundwater flow system of Ejina basin in lower reaches of the Heihe River in Northwest China (Part 1). Hydrogeol. Eng. Geol. 2002, 1, 16-20, (In Chinese with English abstract).

47. Xie, Q. Regional Hydrogeological Survey Report of the People's Republic of China (1:200,000): Ejina K-47-[24] [R]; Chinese People's Liberation Army: Jiuquan, China, 1980. (In Chinese)

48. Wang, P.; Yu, J.; Zhang, Y.; Liu, C. Groundwater recharge and hydrogeochemical evolution in the Ejina Basin, northwest China. J. Hydrol. 2013, 476, 72-86. [CrossRef]

49. Qin, D.; Zhao, Z.; Han, L.; Qian, Y.; Ou, L.; Wu, Z.; Wang, M. Determination of groundwater recharge regime and flowpath in the Lower Heihe River basin in an arid area of Northwest China by using environmental tracers: Implications for vegetation degradation in the Ejina Oasis. Appl. Geochem. 2012, 27, 1133-1145. [CrossRef]

50. Wang, P.; Zhang, Y.; Yu, J.; Fu, G.; Ao, F. Vegetation dynamics induced by groundwater fluctuations in the lower Heihe River Basin, northwestern China. J. Plant Ecol. 2011, 4, 77-90. [CrossRef]

51. Zhang, Y.; Yu, J.; Wang, P.; Fu, G. Vegetation responses to integrated water management in the Ejina basin, northwest China. Hydrol. Process. 2011, 25, 3448-3461. [CrossRef]

52. Yao, Y.; Tian, Y.; Andrews, C.; Li, X.; Zheng, Y.; Zheng, C. Role of Groundwater in the Dryland Ecohydrological System: A Case Study of the Heihe River Basin. J. Geophys. Res. Atmos. 2018, 123, 6760-6776. [CrossRef]

53. Wen, X.; Wu, Y.; Su, J.; Zhang, Y.; Liu, F. Hydrochemical characteristics and salinity of groundwater in the Ejina Basin, Northwestern China. Environ. Geol. 2005, 48, 665-675. [CrossRef]

54. Yang, Q.; Xiao, H.; Zhao, L.; Yang, Y.; Li, C.; Zhao, L.; Yin, L. Hydrological and isotopic characterization of river water, groundwater, and groundwater recharge in the Heihe River basin, northwestern China. Hydrol. Process. 2011, 25, 1271-1283. [CrossRef]

55. Harbaugh, A.W. MODFLOW-2005, the U.S. Geological Survey Modular Ground-Water Model-The Ground-Water Flow Process; U.S. Geological Survey Techniques and Methods 6-A16; U.S. Geological Survey: Reston, VA, USA, 2005.

56. Chiang, W.-H. 3D-Groundwater Modeling with PMWIN: A Simulation System for Modeling Groundwater Flow and Transport Processes, 2nd ed.; Springer: New York, NY, USA, 2005; p. 397.

57. McDonald, M.G.; Harbaugh, A.W. A Modular Three-Dimensional Finite-Difference Ground-Water Flow Model; U.S. Geological Survey: Reston, VA, USA, 1988.

58. Prudic, D.E. Documentation of a Computer Program to Simulate Stream-Aquifer Relations Using a Modular, Finite-Difference, Ground-Water Flow Model; U.S. Geological Survey: Reston, VA, USA, 1989; pp. 88-729.

59. Gates, J.; Edmunds, W.; Ma, J.; Scanlon, B. Estimating groundwater recharge in a cold desert environment in northern China using chloride. Hydrogeol. J. 2008, 16, 893-910. [CrossRef]

60. Zhu, G.F.; Li, Z.Z.; Su, Y.H.; Ma, J.Z.; Zhang, Y.Y. Hydrogeochemical and isotope evidence of groundwater evolution and recharge in Minqin Basin, Northwest China. J. Hydrol. 2007, 333, 239-251. [CrossRef]

61. Hu, S.; Tian, C.; Song, Y.; Chen, X.; Li, Y. Models for calculating phreatic water evaporation on bare and Tamarix-vegetated lands. Chin. Sci. Bull. 2006, 51, 43-50. [CrossRef]

62. Shah, N.; Nachabe, M.; Ross, M. Extinction depth and evapotranspiration from ground water under selected land covers. Ground Water 2007, 45, 329-338. [CrossRef]

63. Du, C.; Yu, J.; Wang, P.; Zhang, Y. Analysing the mechanisms of soil water and vapour transport in the desert vadose zone of the extremely arid region of northern China. J. Hydrol. 2018, 558, 592-606. [CrossRef] 
64. Guo, X.; Feng, Q.; Si, J.; Xi, H.; Zhao, Y.; Deo, R.C. Partitioning groundwater recharge sources in multiple aquifers system within a desert oasis environment: Implications for water resources management in endorheic basins. J. Hydrol. 2019, 579, 124212. [CrossRef]

65. Legates, D.R.; McCabe, G.J., Jr. Evaluating the use of "goodness-of-fit" measures in hydrologic and hydroclimatic model validation. Water Resour. Res. 1999, 35, 233-241. [CrossRef]

66. Wang, P.; Yu, J.; Min, L.; Xu, Y.; Zhu, B.; Zhang, Y.; Du, C. Shallow groundwater regime and its driving forces in the Elina oasis. Quat. Sci. 2014, 34, 982-993, (In Chinese with English abstract).

67. Wang, T.-Y.; Wang, P.; Zhang, Y.-C.; Yu, J.-J.; Du, C.-Y.; Fang, Y.-H. Contrasting groundwater depletion patterns induced by anthropogenic and climate-driven factors on Alxa Plateau, northwestern China. J. Hydrol. 2019, 576, 262-272. [CrossRef]

68. Wang, P.; Grinevsky, S.O.; Pozdniakov, S.P.; Yu, J.; Dautova, D.S.; Min, L.; Du, C.; Zhang, Y. Application of the water table fluctuation method for estimating evapotranspiration at two phreatophyte-dominated sites under hyper-arid environments. J. Hydrol. 2014, 519 Pt B, 2289-2300. [CrossRef]

69. Hill, M.C.; Tiedeman, C.R. Effective Groundwater Model Calibration: With Analysis of Data, Sensitivities, Predictions and Uncertainty; Wiley and Sons: Hoboken, NJ, USA, 2007.

70. Maddock Iii, T.; Baird, K.J.; Hanson, R.T.; Schmid, W.; Ajami, H. RIP-ET: A Riparian Evapotranspiration Package for MODFLOW-2005; 6-A39; US Geological Survey Techniques and Methods 6; U.S. Geological Survey: Reston, VA, USA, 2012; pp. 1-76.

71. Wang, P.; Niu, G.Y.; Fang, Y.H.; Wu, R.J.; Yu, J.J.; Yuan, G.F.; Pozdniakov, S.P.; Scott, R.L. Implementing Dynamic Root Optimization in Noah-MP for Simulating Phreatophytic Root Water Uptake. Water Resour. Res. 2018, 54, 1560-1575. [CrossRef]

(C) 2020 by the authors. Licensee MDPI, Basel, Switzerland. This article is an open access article distributed under the terms and conditions of the Creative Commons Attribution (CC BY) license (http://creativecommons.org/licenses/by/4.0/). 